\title{
conflict resolution in a multi-cultural urban setting in papua new guinea
}

\author{
John Ivoro \\ Mediator in Saraga Settlement \\ Port Moresby, Papua New Guinea
}

\section{Personal, Work and Cultural Background}

My name is John Ivoro and I was born in the Goilala District in the Central Province of Papua New Guinea. I attended primary school there and then went on to Bereina De La Salle High School as a boarder where I completed Grade 10. After completing Grade 10, I studied at the College of Allied Health and Sciences in Port Moresby for nearly three years. Because I needed to earn money to fulfil family obligations, I left before graduation and began work in the PNG Tax Office in 1980. When I started with the Tax Office, I moved to the Saraga Settlement in Port Moresby to live with members of my family. In 1990 I left the Tax Office and became involved with the Peace Foundation Melanesia (PFM) training program in 'People Skills and Conflict Resolution'. During 1996-99, I was a program trainer in Port Moresby and also worked in other parts of PNG including the Highlands and Bougainville.

\section{Current Situation}

The section of Saraga Settlement where I live has a population of approximately 4,000. The people are mainly Highlanders, Goilalas, Motu Koitabuans, inland Rigos and some are from the Oro Province. They tend to live with their own ethnic groups for 
cultural and, more importantly, security reasons. Before we started our conflict resolution work, life in the settlement was uncertain and insecure. There was a lot of crime and violence. Women, in particular, were fearful for their personal security and welfare. Drinking was often the catalyst for fights erupting between ethnic groups. This was an ethnically divided community dominated by males and, in practice, women stayed very much in the background.

It was into this environment that the Peace Foundation Melanesia introduced the techniques of conflict resolution. During the three years between 1996 and 1999, the Foundation conducted about 60 courses in People Skills and Conflict Resolution. Having become a certified trainer, I assisted others to set up the Ivani/Saraga Dispute Settlement Committee in 1997. Entirely recruited from the local community, most committee members had already attended PFM courses that had taught them skills in conflict mediation, project planning and some methods of restorative justice. Our shared training ensured that we were able to apply a common method. That method is explained in John Tombot's chapter on Bougainville (this volume). Drawing on our initial training, we added on aspects of our respective cultural ways of settling disputes. Variations in the mediation processes reflected the different cultural backgrounds of individual mediators. People from a particular cultural group would conduct the mediations within their own group. However, at times, experienced mediators were asked to support mediations outside their cultural groups so as to ensure that methods and processes were being applied properly and fairly.

Mediation was initiated after a request had been received from a group or an individual. Usually mediations were conducted on Sunday evenings at a community meeting. These meetings also provided the opportunity to discuss broader community issues. If a major dispute arose during the week the matter would be mediated immediately. When a mediation was completed the agreement was registered in a Mediation Book which was kept by the Mediation Recorder. The information contained in the Mediation Book was forwarded to Br. Pat 
Howley, training director of the Peace Foundation. Over the past three years we have conducted over 200 successful mediations.

When agreements are not honoured, the aggrieved party can seek redress before the Village Court. As the Village Court is aware of our work, it will often ask us for background and other relevant information about the case.

Our Dispute Settlement Committee has established links with a number of government, private sector and nongovernment organisations, as well as with prominent local figures. These include: Saraga Village Court, 6 Mile Police Station, Peace Foundation Melanesia, Downer Constructions Pty Ltd, Monier Pty Ltd, Hebou Constructions Pty Ltd, Lady Carol Kidu (a national politician), and the Parish Priest at Holy Rosary Church. We started working with these groups because mediation had taught us that conflicts often arose because basic needs were not being met. The Settlement Committee went out of its way to negotiate with nearby construction companies to see if they could employ some of our unskilled young people in casual labouring roles. We argued that this would help to minimise and/or prevent law and order problems in the community. We have also approached the same companies for assistance to build a community hall. This matter is still under negotiation.

We link up with the police for a number of reasons. If things really get out of hand, we call in the police to settle the community down so we can consider mediation. If troublemakers are from outside our area, then we refer them to the police. In other situations, the police may be investigating a crime or may have already made arrests. Where they know that the suspect comes from our area, they are likely to refer the matter to our committee for mediation.

Our links with the churches have been used primarily to encourage spiritual and club activities with women and youth, although we also use church personnel for mediation purposes.

The committee has deliberately adopted a broad approach to conflict resolution, recognising that mediation alone will not solve our problems. We appreciate that, in order to be successful, our conflict resolution work has to be integrated 
into a broader development strategy that attempts to address the basic needs of our community.

\section{Impact on and Benefits for the Community}

The courses that we have run with the assistance of the Peace Foundation have helped break down barriers between ethnic groups. All courses have a mixture of participants in terms of gender, age and ethnic background. This has reduced fear and uncertainty and increased freedom of movement in the settlement. For example, women now feel free to sit out at night, talking and selling betel nut and cigarettes. This did not happen before. These changes have been supported by the introduction of street lighting, following negotiations with ELCOM and the National Capital District Commission. Their main concern was with vandalism but the courses and discussions with our youth have helped reduce this problem.

Another result is that Downer Construction Company's Managing Director, Mr Greg Wright, has come to understand our problems and has provided support in a number of areas, including casual employment for youth, sponsorship of the Saraga Sporting Competition for both males and females, provision of refreshments for church activities, and sponsorship of transport to enable our local rugby league team to play in places outside Port Moresby. We plan to negotiate with other companies in the future.

Six Mile Police Station recognises and accepts the work of the committee. The police now work with us on community matters and support the mediation approach adopted by the committee. Saraga Village Court also acknowledges the role of the Dispute Settlement Committee and refers many cases to us for preliminary mediation. The Peace Foundation Melanesia invites our members to participate in workshops and forums whenever they are held.

\section{The future}

In order to build on our initial success, the committee needs a resource centre or building where: 
- $\quad$ mediators can work;

- $\quad$ community activities can be planned and conducted;

- $\quad$ community groups can hold meetings and conduct activities;

- $\quad$ training programs can be conducted and other activities organised.

We also need:

- $\quad$ ongoing training for mediators;

- $\quad$ recognition from the Government;

- basic stationeary supplies;

- allowances; and

- $\quad$ more support from the Government and the private sector to deliver basic needs.

\section{A case study in bride price}

In 1999 I was asked to be a mediator in the following case.

A young man, Peter Kom, married Theresa back in the village at Woitape (Central Province). Theresa's parents were in Port Moresby and, upon hearing about this, they demanded that Peter Kom send his sister, named Kavap, down to Port Moresby to be married to Theresa's brother, Tom. It was their custom to make such exchanges part of a bride price arrangement. Tom was still at school in Port Moresby and about to finish grade 10. He was, however, already engaged to Lucy, a girl from the same area and he wanted to marry her. Kavap found this out when she arrived in Port Moresby.

The complications set in motion by the request of Tom's parents in respect of Tom, Lucy and Kavap, led to a number of decisions based on the traditional way of paying bride price in their culture. The key decisions were:

That it was correct for Kavap to become the first wife of Tom, and that Tom need not pay any more bride price as Tom's sister was already married to Kavap's brother, Peter Kom, back in the village. That Tom now had to pay some form of bride price to Lucy's parents and relatives in Port Moresby at a time to be set. In accordance with existing cultural practices, he could have two wives. Tom and his two wives are now living happily together. 